\title{
IMPLEMENTASI PROGRAM NASIONAL PEMBERDAYAAN MASYARAKAT (PNPM) MANDIRI DALAM MENGATASI KEMISKINAN PERKOTAAN DI KECAMATAN NUSANIWE, KOTA AMBON
}

\author{
Oleh Nancy Rahakbauw. S.Sos., M.Si*
}

\begin{abstract}
This study aims to to understand the process of beneficiaries and the direct impact of a government program of PNPM Mandiri P2KP as an attempt to improve the welfare of the community, in terms of environmental, economic and social held in District Nusaniwe, Ambon.

PNPM Mandiri P2KP is empowerment program for people who are not economically able to pay for his life and lived in the house uninhabitable. The process is carried out to provide assistance to beneficiaries are those who fall into the category of poor that are listed in the list of poor people or people can not afford. In addition, the PNPM Mandiri P2KP beneficiaries are citizens who are impaired in terms of transportation such as roads dan bridges that impede their access to improve their welfare. Programs provided by the government is more focused on environmental, economic and social.
\end{abstract}

Based on the findings, the impact is felt by beneficiaries of government aid is no increase in the welfare of both individuals and society, and hoped that similar programs could be improved further.

Keywords: the poor, empowerment, welfare

\section{Abstrak}

Penelitian ini bertujuan untuk mengetahui proses penerima bantuan dan dampak langsung dari program pemerintah PNPM Mandiri P2KP sebagai upaya untuk peningkatan kesejahteraan masyarakat,baik dari aspek lingkungan, ekonomi maupun sosial yang dilaksanakan di Kecamatan Nusaniwe, Kota Ambon.

PNPM Mandiri P2KP adalah program pemberdayaan bagi orang yang secara ekonomi tidak dapat membiayai hidupnya dan tinggal di rumah yang tidak layak huni. Proses yang dilakukan untuk memberikan bantuan kepada penerima manfaat adalah orang-orang yang masuk dalam kategori miskin yang terdaftar dalam daftar warga miskin atau orang tidak mampu. Disamping itu, penerima bantuan PNPM Mandiri P2KP adalah warga masyarakat yang mengalami gangguan dalam hal transportasi seperti jalan dan jembatan sehingga menghambat akses mereka dalam meningkatkan kesejahteraan hidupnya. Program yang diberikan pemerintah lebih menitikberatkan pada lingkungan, ekonomi dan sosial.

Berdasarkan temuan penelitian, dampak yang dirasakan oleh penerima bantuan pemerintah adalah ada peningkatan kesejahteraan baik secara individu maupun masyarakat, dan berharap agar program-program serupa dapat ditingkatkan lagi.

Kata Kunci: orang miskin, pemberdayaan, kesejahteraan

\section{Pendahuluan}

Pembangunan di Indonesia merupakan amanat sebagaimana ditetapkan dalam UUD 1945, dimana tujuan Negara Indonesia adalah untuk melindungi segenap bangsa dan seluruh tumpah darah Indonesia, memajukan kesejahteraan umum, mencerdaskan kehidupan bangsa, dan ikut melaksanakan ketertiban dunia. Pembangunan nasional mencakup upaya peningkatan semua aspek kehidupan bangsa.
Pemahaman akan masalah yang dihadapi individu atau masyarakat membuka wacana pemikiran kita tentang bagaimana meminimalisir kondisi atau situasi sulit masyarakat agar kebutuhan hidup mereka dapat terpenuhi. Hidup yang sejahtera menjadi dambaan setiap warga masyarakat.Untuk mewujudkan kondisi tersebut, maka wajar apabila berbagai upaya ditempuh dalam mengatasi atau mengeliminir faktor-faktor yang menghambat pencapaian kondisi ideal 
tersebut.Fenomena yang disebut sebagai masalah sosial dianggap sebagai kondisi yang dapat menghambat perwujudan kesejahteraan sosial.Oleh karena itu masalah sosial seringkali disebut sebagai kondisi sosial yang tidak diharapkan, dengan demikian kemunculannya selalu mendorong tindakan untuk melakukan perubahan dan perbaikan.

Pembangunan kesejahteraan sosial adalah usaha yang terencana dan melembaga yang meliputi berbagai bentuk intervensi sosial dalam pelayanan sosial untuk memenuhi kebutuhan manusia, mencegah dan mengatasi masalah sosial, serta memperkuat institusi-institusi sosial (Suharto, 1997).Tujuan Pembangunan Kesejahteraan Sosial (PKS) adalah untuk meningkatkan kualitas hidup manusia secara menyeluruh. Ciri utama pembangunan kesejahteraan adalah komprehensif atau terpadu dalam arti setiap pelayanan sosial yang diberikan senantiasa menempatkan penerima pelayanan (beneficiaries) sebagai manusia, baik dalam arti individu maupun kolektivitas yang tidak terlepas dari sistim lingkungan sosial kulturalnya, sasaran pembangunan kesejahteraan sosial (PKS) adalah seluruh masyarakat dari berbagai golongan atau kelas sosial. Namun prioritas utama PKS adalah kelompok-kelompok yang kurang beruntung (disadvantage groups). Sasaran PKS yang biasanya dikenal dengan nama PMKS atau penyandang masalah kesejahteraan sosial/pemerlu pelayanan kesejahteraan sosial, antara lain meliputikeluarga miskin.Jumlah angka kemiskinan di Maluku berdasarkan data BPS tahun 2014 mencapai 316.110 orang $(19,13$ persen). Jika dibandingkan dengan tahun 2013 penduduk miskin berjumlah 315.990 orang $(19,49$ persen), dalam satu tahun ini tingkat kemiskinan turun sebanyak 0,36 persen walaupun dari sisi jumlah, pendudukmiskinbertambah sebanyak 120 orang.

Program Nasional Pemberdayaan Masyarakat Mandiri (PNPM Mandiri) Program Penanggulangan Kemiskinan di Perkotaan (P2KP) adalah prakarsa baru dari Pemerintah Republik Indonesia yang ditujukan untuk mengatasi persoalan kemiskinan di perkotaan yang jumlahnya makin bertambah. Program ini dirancang untuk menanggulangi kemiskinan secara berkelanjutan sehingga diperlukan pendekatan yang berbasis pada prinsip-prinsip pemberdayaan komunitas (community based development). Untuk itu perlu upaya tertentu yang harus dilakukan oleh komunitas itu sendiri, terutama pada level pemerintah paling bawah yaitu desa/kelurahan.

Program Penanggulangan Kemiskinan di Perkotaan (P2KP) masuk ke Kota Ambon sejak tahun 2006 (tahun pertama) yang ditetapkan 23 wilayah sasaran di Kota Ambon, akan tetapi untuk mengawali pelaksanaannya sementara ditetapkan 4 Kelurahan sebagai wilayah percontohan kegiatan P2KP di Provinsi Maluku yang terpusat di Kota Ambon dengan lokasi sasaran yaitu Kelurahan Batu Gajah, Kelurahan Honipopu, Kelurahan Waihaoung, dan Kelurahan Urimesing.Sementara sisanya 19 lokasi baru bisa dilaksanakan pada tahun 2007. Paralel dengan itu, pada tahun 2007 itu juga ditetapkan pula lokasi sasaran baru yaitu 27 lokasi sasaran di Kota Ambon, sehingga untuk Kota Ambon seluruh Desa dan Kelurahan mendapatkan pendampingan dari P2KP.

Program-program pengentasan kemiskinan baik di pedesaan maupun perkotaan sebagai wujud upaya pemerintah dalam meningkatkan taraf hidup masyarakat secara kualitas maupun kuantitas. Upaya-upaya ini memberikan kesempatan kepada masyarakat dengan kondisi ekonomi lemah agar mampu memperbaiki kehidupan yang lebih baik menuju kepada kondisi kesejahteraan yang diharapkan, meskipun upaya ini belum maksimal.

\section{Kerangka Teoritis}

2.1. Kemiskinan

a. Konsep Kemiskinan

Kemiskinan merupakan masalah kompleks yang dipengaruhi oleh berbagai faktor yang saling berkaitan, antara lain: tingkat pendapatan, kesehatan, pendidikan, akses terhadap barang dan jasa, lokasi, geografis, gender, dan kondisi lingkungan. Mengacu pada strategi nasional penanggulangan kemiskinan definisi kemiskinan adalah kondisi di mana seseorang atau sekelompok orang, laki-laki dan perempuan, tidak terpenuhi hak-hak dasarnya untuk mempertahankan dan mengembangkan kehidupan yang bermartabat. Definisi ini beranjak dari pendekatan berbasis hak yang mengakui bahwa masyarakat miskin mempunyai hak-hak dasar yang sama dengan anggota masyarakat lainnya.

Kemiskinan tidak lagi dipahami hanya sebatas ketidakmampuan ekonomi, tetapi juga kegagalan memenuhi hak-hak dasar dan perbedaan perlakuan bagi seseorang atau sekelompok orang dalam menjalani kehidupan secara bermartabat. Hak-hak dasar yang diakui 
secara umum meliputi terpenuhinya kebutuhan pangan, kesehatan, pendidikan, pekerjaan, perumahan, air bersih, pertanahan, sumberdaya alam, dan lingkungan hidup, rasa aman dari perlakukan atau ancaman tindak kekerasan dan hak untuk berpartisipasi dalam kehidupan sosialpolitik, baik bagi perempuan maupun laki-laki.

Pemikiran mengenai kemiskinan berubah sejalan dengan berlalunya waktu, tetapi pada dasarnya berkaitan dengan ketidakmampuan untuk memenuhi kebutuhan dasar (Mikelsen, 2003:194). Kemiskinan menunjukkan situasi serba kekurangan yang terjadi bukan karena dikehendaki oleh si miskin, melainkan karena tidak bisa dihindari dengan kekuatan yang dimilikinya (Soegijoko, 1997:137). Menurut Sar A. Levitan dalam Ala (1981:3) menyatakan kemiskinan adalah kekurangan barang-barang dan pelayanan-pelayanan yang dibutuhkan untuk mencapai suatu standar hidup yang layak. Sedangkan menurut Badan Pusat Statistik dan Departemen Sosial (2002:3-4) kemiskinan adalah ketidakmampuan individu dalam memenuhi kebutuhan dasar minimum untuk hidup layak.Kemiskinan terjadi ketika seseorang atau sekelompok orang, baik laki-laki dan perempuan, tidak terpenuhi hak-hak dasarnya untuk mempertahankan dan mengembangkan kehidupan yang bermartabat (Perpres Nomor 7 Tahun 2005 tentang RPJMN). Definisi ini beranjak dari pendekatan berbasis hak yang mengakui bahwa masyarakat miskin mempunyai hak-hak dasar yang sama dengan anggota masyarakat lainnya. Ketidaksamaan kesempatan untuk mengakumulasi basis kekuatan sosial yang meliputi: aset, sumbersumber keuangan, organisasi dan jaringan sosial, pengetahuan dan informasi untuk memperoleh pekerjaan menjadikan seseorang menjadi miskin (John Friedman [1979] dalam Ridlo [2001:8]).

Definisi kemiskinan dapat dilihat dari tinjauan ekonomi, sosial dan politik.Secara ekonomi kemiskinan adalah kekurangan sumber daya yang dapat digunakan untuk meningkatkan kesejahteraan. Dari segi sosial kemiskinan diartikan kekurangan jaringan sosial dan struktur untuk mendapatkan kesempatan-kesempatan meningkatkan produktivitas.Sedangkan secara politik kemiskinan diartikan kekurangan akses terhadap kekuasaan (Effendi, 1993:201-204).

Tinjauan yang sama dengan dengan penjelasan berbeda dikemukakan Nugroho dan Dahuri (2004:165-166). Dari aspek ekonomi, kemiskinan merupakan kesenjangan antara lemahnya daya pembelian (positif) dan keinginan untuk memenuhi kebutuhan dasar (normatif).Dari aspek sosial, kemiskinan mengindikasikan potensi perkembangan masyarakat yang rendah.Sedangkan dari aspek politik, kemiskinan berhubungan dengan rendahnya kemandirian masyarakat.Badan Koordinasi Keluarga Berencana Nasional (2003:25) memberikan definisi kemiskinan dengan basis keluarga.Keluarga yang termasuk kategori miskin adalah keluarga pra sejahtera dan keluarga sejahtera I alasan ekonomi. Keluarga Pra Sejahtera, yaitu keluarga yang belum dapat memenuhi kebutuhan dasar secara minimal, seperti kebutuhan pengajaran agama, pangan, sandang, papan dan kesehatan. Sedangkan Keluarga Sejahtera I, yaitu keluarga yang telah dapat memenuhi kebutuhan dasar secara minimal tetapi belum memenuhi seluruh kebutuhan sosio psikologinya seperti kebutuhan pendidikan, interaksi dalam keluarga dan lingkungan dan transportasi.

Menurut Rusli, dkk (1995:51-52), harus dibedakan antara kemiskinan, ketidakmerataan, keterisolasian dan keterbelakangan. Kemiskinan adalah suatu kondisi dimana orang atau sekelompok orang tidak dapat memenuhi standar kebutuhahan minimum tertentu.Ketidakmerataan lebih menekankan pada standar hidup relatif diantara anggota masyarakat. Keterisolasian menyangkut ketidakmampuan sekelompok orang untuk berhubungan secara teratur dan mudah dengan masyarakat lainnya, sedangkan keterbelakangan menyangkut kurangnya kesadaran dan pengetahuan mengenai kebutuhan serta kondisi kehidupan yang lebih baik.

Dengan jumlah dan persentase penduduk perkotaan yang semakin besar dan semakin padat tersebut tentu akan menambah "beban hidup" perkotaan yang semakin berat sehingga menimbulkan berbagai permasalahan yang semakin kompleks di bidang-bidang sosialekonomi, sosial-budaya, politik-pemerintahan, ketertiban dan keamanan, dan sebagainya. Diantara berbagai permasalahan tersebut yang menonjol diantaranya adalah yang berhubungan dengan kemiskinan perkotaan yang meliputi kondisi sangat kurang tercukupi kebutuhannya atas pelayanan kebutuhan dasar mereka seperti air bersih, sanitasi, saluran air dan jalan akses. Kondisi ini terjadi antara lain karena kurangnya bantuan dan penanganan pemerintah, baik berupa pemeliharaan maupun investasi baru atas infrastruktur lingkungan yang diperlukan masyarakat setempat. 
Menurut hasil survai ternyata relatif lebih banyak rumah tangga di perkotaan yang tidak memiliki akses air bersih dibandingkan rumah tangga di pedesaan. Banyak di antara kaum miskin perkotaan yang terpaksa membeli air bersih, dan bahkan mereka tergantung pada fasilitas air minum "swasta" yang lebih mahal.Demikian pula dalam hal fasilitas toilet, kondisinya serba kurang dan menyedihkan.

\section{b. Penyebab Kemiskinan}

Penyebab kemiskinan dapat terjadi karena kondisi alamiah dan ekonomi, kondisi struktural dan sosial, serta kondisi kultural (budaya). Kemiskinan alamiah dan ekonomi timbul akibat keterbatasan sumber daya alam, manusia, dan sumberdaya lain sehingga peluang produksi relatif kecil dan tidak dapat berperan dalam pembangunan. Kemiskinan struktural dan sosial disebabkan hasil pembangunan yang belum merata, tatanan kelembagaan dan kebijakan dalam pembangunan. Sedangkan kemiskinan kultural (budaya) disebabkan sikap atau kebiasaan hidup yang merasa kecukupan sehingga menjebak seseorang dalam kemiskinan (Nugroho dan Dahuri, 2004:167-168; Soegijoko, 1997:137; dan Nasution, 1996: 48-50).

Penyebab kemiskinan menurut Cox (2004:1-6) berupa: (1) Kemiskinan yang diakibatkan globalisasi berupa dominasi negaranegara maju terhadap negara-negara berkembang; (2) Kemiskinan yang berkaitan dengan pembangunan berupa rendahnya partisipasi dalam pembangunan dan peminggiran proses pembangunan; (3) Kemiskinan sosial yang yang dialami oleh perempuan, anak-anak dan kelompok minoritas karena ketidakberdayaan mereka; dan (4) Kemiskinan karena faktor-faktor eksternal seperti konflik, bencana alam, kerusakan lingkungan dan tingginya jumlah penduduk. Sedangkan Sharp et. al. dalam Kuncoro (2004:157) mencoba mengidentifikasi penyebab kemiskinan dipandang dari sisi ekonomi. Pertama, ketidaksamaan pola kepemilikan sumber daya yang menimbulkan distribusi pendapatan yang timpang. Kedua, perbedaan dalam kualitas sumber daya manusia yang berkaitan dengan produktivitas dan upah yang rendah.Ketiga, kemiskinan muncul akibat perbedaan akses dalam modal.Penyebab kemiskinan menurut masyarakat miskin sendiri adalah kurangnya modal, pendidikan, keterampilan, dan kesempatan kerja; dan rendahnya pendapatan (Tim Studi KKP, 2004).

\section{c. Jenis Kemiskinan}

Pembagian jenis kemiskinan dapat dibagi berdasarkan pola waktu.Ginandjar Kartasasmita dalam Ridlo (2001:11) mengatakan, menurut pola waktu tersebut kemiskinan dapat dibagi menjadi: (1) Persistent poverty, yaitu kemiskinan yang telah kronis atau turun-temurun yang diantaranya merupakan daerah kritis sumber daya alam atau terisolasi; (2) Cyclical poverty yaitu kemiskinan yang mengikuti pola siklus ekonomi secara keseluruhan; (3) Seasonalpoverty, yaitu kemiskinan musiman seperti sering dijumpai kasus-kasus nelayan dan petani tanaman pangan; dan (4) Accidental poverty, yaitu kemiskinan karena bencana alam atau dampak dari suatu kebijakan.

Berdasarkan jenisnya kemiskinan secara umum dapat dibagi menjadi kemiskinan absolut dan kemiskinan relatif. Kemiskinan absolut terjadi apabila tingkat pendapatan seseorang di bawah garis kemiskinan absolut yang telah ditetapkan, sehingga tidak dapat memenuhi kebutuhan hidup minimum yang antara lain terdiri dari kebutuhan sandang, pangan, kesehatan, perumahan dan pendidikan. Sedangkan kemiskinan relatif merupakan perbandingan antara kelompok pendapatan dalam masyarakat tersebut.Meskipun seseorang/masyarakat telah dapat memenuhi kebutuhan dasarnya secara layak (tidak miskin), tetapi masih rendah kualitasnya dibandingkan masyarakat sekitarnya yang relatif lebih kaya (Soegijoko, 1997 dan Esmara, 1986) dalam Ridlo (2001:10). Kemiskinan absolut keberadaannya masih dapat dihilangkan (povertyalleviation), sedangkan kemiskinan relatif keberadaannya tidak dapat dihilangkan, tetapi hanya dapat dikurangi intensitasnya (poverty reduction) (Soegijoko, 1997:138).

\subsection{Pemberdayaan Masyarakat}

Pembangunan kesejahteraan sosial dalam arti luas pada dasarnya juga merupakan suatu upaya pemberdayaan masyarakat. Berbagai upaya yang dilakukan terhadap kelompok sasaran seringkali diidentikkan sebagai upaya yang memberdayakan (mengembangkan kelompok sasaran dari keadaan tidak atau kurang berdaya menjadi mempunyai daya) guna mencapai kehidupan yang lebih baik. (Adi, 2002: 161-162). Secara konseptual, pemberdayaan (empowerment) berasal dari kata power yang berarti kekuatan atau kekuasaan. Oleh karena itu, ide utama pemberdayaan ini selalu bersentuhan dengan konsep kekuasaan. 
Ife (1995: 182) juga menjelaskan:

"Empowerment means providing people with the resources, opportunity, knowledge, and skill to increase their capacities to determine their own future, and to participate in and affect of their community." (pemberdayaan berarti menyiapkan kepada masyarakat berupa sumber daya, kesempatan, pengetahuan, dan keahlian untuk meningkatkan kapasitas diri masyarakat di dalam menentukan masa depan mereka, serta berpartisipasi dan mempengaruhi kehidupan dalam komunitas itu sendiri).

Selain itu, Ife (1995: 56) menambahkan, "Empowerment aims to increase the power of disadvantaged" (pembangunan bertujuan untuk meningkatkan kekuatan dari mereka yang kurang beruntung.

Pendapat Ife ini sejalan dengan Kabeer (2001: 19) yang menyatakan bahwa kekuasaan adalah kemampuan untuk membuat pilihan. Lebih lanjut menurut Kabeer, pilihan di sini dapat diartikan sebagai kemampuan untuk memilih hal lain sebagai alternatif. Kabeer menyebutkan, "Empowerment thus refers to the expansion in people's ability to make strategic life choices in a context where this ability was previously denied to them." (Pemberdayaan merujuk pada ekspansi kemampuan seseorang untuk membuat pilihan hidup yang strategis dalam konteks di mana kemampuan ini sebelumnya tidak diakui).

Sejalan dengan Ife dan Kabeer, Alsop, dkk (2006: 10) mendefinisikannya sebagai berikut: Empowerment is defined as a group's or individual's capacity to make effective choice, that is, to make choices and then to transform those choices into desired actions and outcomes." (Pemberdayaan diartikan sebagai kapasitas kelompok atau individu untuk membuat pilihan yang efektif, yaitu membuat pilihan dan kemudian mengubah pilihan tersebut ke dalam tindakan atau hasil yang diharapkan). Di sini Alsop menekankan bahwa suatu pemberdayaan akan berjalan dengan baik apabila kelompok atau individu memiliki dan menentukan pilihan atas sumber.

Kemudian Hogan mengemukakan bahwa pemberdayaan individu merupakan proses yang relatif terus berjalan sepanjang usia manusia yang diperoleh dari pengalaman individu tersebut dan bukan suatu proses yang berhenti pada suatu masa saja. Menurutnya, "Empowerment is not an endstate, buat a process that all humanbeings experiences." (Adi, 2002: 165)
Hal ini juga berlaku pada suatu pemberdayaan masyarakat, di mana dalam suatu komunitas, proses pemberdayaan masyarakat tidak akan berakhir dengan selesainya suatu program, baik program yang dilaksanakan oleh pemerintah maupun lembaga non pemerintah. Proses pemberdayaan akan berlangsung selama komunitas itu tetap ada dan mau berusaha untuk memberdayakan dirinya.

Chambers (Kartasasmita, 1996:

menyatakan, pemberdayaan masyarakat adalah sebuah konsep pembangunan ekonomi yang merangkum nilai-nilai sosial. Konsep ini mencerminkan paradigma baru pembangunan, yakni bersifat "people centered, participatory, empowering, and sustainable." Sedangkan Kartasasmita menjelaskan bahwa memberdayakan masyarakat adalah upaya untuk meningkatkan harkat dan martabat lapisan masyarakat yang dalam kondisi sekarang tidak mampu untuk melepaskan diri dari perangkap kemiskinan dan keterbelakangan (1996: 144).

Sebagai suatu program, pemberdayaan dilihat dari tahap-tahap kegiatan guna mencapai tujuan, yang biasanya telah ditentukan jangka waktunya. Pemberdayaan sebagai suatu program harus direncanakan secara serius dan lebih memfokuskan pada upaya-upaya yang membuat masyarakat agar dapat lebih pandai, mampu mengembangkan komunikasi antar mereka, sehingga pada akhirnya mereka dapat saling berdiskui secara konstruktif dan mengatasi permasalahan yang ada. Jadi ketika agen perubah berasal dari luar (baik itu berasal dari lembaga pemerintah maupun non pemerintah), telah menyelesaikan programnya maka pemberdayaan sebagai proses tetap berlangsung pada kelompok sasaran tersebut (Adi, 2002: 176).

Tahapan intervensi sosial dalam program pemberdayaan masyarakat merupakan suatu siklus perubahan yang berusaha mencapai ke taraf yang lebih baik (Adi, 2002: 179). Menurut Wrihatnolo dan Dwidjowijoto (2007: 1), dengan menekankan pada proses, maka pemberdayaan masyarakat memiliki tahap-tahap sebagai berikut:

a.Penyadaran

Pada tahap ini dilakukan sosialisasi terhadap komunitas agar mereka mengerti bahwa kegiatan pemberdayaan ini penting bagi peningkatan kualitas hidup mereka dan dilakukan secara mandiri (self help).

b.Pengkapasitasan

Sebelum diberdayakan, komunitas perlu diberikan kecakapan dalam mengelolanya. 
Tahap ini sering disebut sebagai capacity building, yang terdiri atas pengkapasitasan manusia, organisasi, dan sistem nilai.

c.Pendayaan

Pada tahap ini, target diberikan daya, kekuasaan, dan peluang sesuai dengan kecakapan yang sudah diperolehnya.

\section{Metodologi Penelitian}

\subsection{Jenis Penelitian}

Penelitian ini dilakukan bersifat deskriptif kualitatif. Penelitian ini dilakukan dengan pendekatan dengan cara tatap muka langsung dan berinteraksi dengan orang-orang ditempat penelitian.

\subsection{Lokasi Penelitian}

Penelitian ini dilakukan di Kecamatan Nusaniwe Kota Ambon karena merupakan salah satu kecamatan yang menjadi sasaran program PNPM Mandiri P2KP.

\subsection{Populasi dan Sampel Penelitian}

Populasi penelitian ini adalah keluarga miskin yang diidentifikasi sesuai dengan data warga miskin di Kecamatan Nusaniwe. Sampel diambil secara random sederhana, yang mewakili warga miskin. Jumlah sampel 39orang.

\subsection{Teknik Pengumpulan Data}

Teknik pengumpulan data dilakukan dengan menggunakan teknik observasi dan wawancara.

\section{Hasil dan Pembahasan}

\subsection{BKM (Badan Keswadayaan Masyarakat)}

\section{a. Proses Seleksi}

Dalam mengimplementasikan program yang akan digunakan oleh masyarakat, maka pemberi manfaat melakukan desiminasi informasi kepada masyarakat tentang program yang akan dijalankan di suatu wilayah, agar masyarakat dapat memahami dan mengerti tentang tujuan program yang dimaksud. Pemahaman terhadap sebuah program sangat penting bagi pelaksanaannya yang akan dilakukan oleh penerima manfaat.

Berdasarkan temuan di lapangan, dari 13 BKM yang diwawancarai, hampir 99\% mengatakan bahwa penentuan seseorang menjadi kooordinator atau ketua BKM dilaksanakan melalui proses pentahapan dari tingkat RT sampai di tingkat desa/kelurahan. Proses pentahapan yang dilakukan adalah:

\section{Pemilihan di tingkat RT}

Pemilihan dilakukan oleh warga dengan kesepakatan bersama dalam mencapai tujuan untuk memilih salah satu warga menjadi wakil di tingkat desa/kelurahan.

2. Pemilihan di Tingkat Desa/Kelurahan

Setelah melalui pemilihan di tingkat desa, maka wakil-wakil dari masing-masing RT akan bersaing memperebutkan suara terbanyak untuk di tetapkan sebagai koordinator atau ketua BKM juga disaksikan oleh Faskel maupun bapak/ibu Kepala Desa/ Lurah.

3. Sosialisasi Program Oleh Faskel (Fasilitator Kelompok)

Proses pemilihan ketua/ koordinator BKM dilaksanakan kemudian Fasilitator Kecamatan menyampaikan program secara terperinci kepada para anggota maupun ketua BKM.

Sementara yang 1\% BKM tidak dipilih melalui proses yang seharusnya dilakukan. BKM ditunjuk secara langsung oleh Faskel untuk menjadi koordinator untuk dapat mengkoordinir anggota-anggotanya pada saat implementasi program yang akan dilaksanakan.

\section{b. Kriteria Penentuan Ketua atau Koordinator $B K M$}

Dari temuan yang ada, seseorang yang dipilih atau ditunjuk oleh warga maupun Faskel sebagai ketua/koordinator adalah orang yang memiliki tanggung jawab serta integritas yang tinggi dalam menjalankan program yang diberikan oleh Pemerintah serta mempunyai rasa sensivitas terhadap lingkungan sosialnya yang besar dan meemiliki interaksi yang baik dengan warga penerima manfaat. Berdasarkan hasil wawancara maupun pengamatan yang dilakukan oleh evaluator, tergambar bahwa dari 13 orang koordinator BKM yang diberikan mandat untuk menjalankan program, pada 6 desa/ kelurahan, koordinator BKM-nya telah memasuki masa pensiun namun masih bekerja untuk pelayanan masyarakat. Sementara 7 orang koordinator BKM yang lain, masih melaksanakan tugas dan tanggungjawabnya di luar BKM. Gambaran secara umum kriteria yang dimiliki oleh BKM berdasarkan fokus program pada nilai-nilai kemanuasian, yaitu:

1. Jujur

2. Bertanggung Jawab

3. Mempunyai atau memilliki sense of belonging terhadap program yang ada

4. Memiliki integritas dan loyalitas

5. Terbuka 


\section{c. Sistem Pengarsipan Dokumen-Dokumen Program Kegiatan}

Tidak dapat dipungkiri bahwa arsip atau dokumen memiliki peran yang sangat penting dalam suatu kegiatan ataupun program yang dilakukan. Kelengkapan dokumen akan memberikan kemudahan bagi BKM sendiri dalam melihat setiap progress dari kegiatan yang dilakukan, bukan hanya secara lisan tetapi juga secara tertulis. Berdasarkan temuan, kelemahan di dalam menata dokumen-dokumen yang terkait dengan program, hal ini ditemukan hampir di semua desa/kelurahan, namun ada satu kelurahan yang memiliki data yang sangat lengkap seperti Kelurahan Benteng. Disamping lemahnya tata kelola administrasi, juga tidak tampak struktur lembaga yang mendeskripsikan tugas dan fungsi masing - masing orang, dari ke 13 desa/kelurahan yng ada, kami hanya melihat satu desa yang menjelaskan tentang struktur kelembagaan yaitu BKM Sejahtera Wainitu.

\section{d. Sistem Interelasi Antara BKM dan Perangkat} Desa

BKM merupakan sebuah lembaga keswadayaan yang berada dalam wilayah kekuasaan kepala desa atau lurah sudah selayaknya melakukan koordinasi dengan pihakpihak aparatur desa/kelurahan, meskipun BKM tidak bertanggung jawab secara langsung pada mereka. Berdasarkan temuan di lapangan bahwa sepanjang proses kegiatan berlangsung ketua/koordinator tetap menjalin relasi dengan pihak desa/kelurahan dalan rangka untuk meningkatkan kualitas hidup warga yag ada di wilayah tersebut. Hal ini terlihat dari adanya kesempatan yang diberikan kelurahan atau desa kepada BKM untuk menggunakan ruang di kantor kelurahan atau desa untuk menjalankan kegiatan P2KP. Seperti yang ditemukan ketikan evaluator melalukan wawancara dengan ketua BKM di Wainitu, Silale, Waihaong, Mangga Dua, serta Kelurahan Benteng. Koordinasi dan keterbukaan yang dilakukan mempermudah proses bagi kedua belah pihak dalam melakukan pengonntrolan terhadap program yang dilaksanakan.

Terkait interelasi yang terjalin di antara BKM dan perangkat desa, ada beberapa BKM yang hubungannya tidak begitu kondusif dengan pihak kelurahan maupun desa. Hal ini disebabkan kurangnya komunikasi yang dibangun sehinga menimbukan kesalapahaman di antara BKM dan pihak desa/kelurahan. Hasil temuan di lapangan memberi indikasi adanya hubungan yang kurang harmonis antara pihak kelurahan dengan BKM, seperti misalnya yang terjadi di kelurahan Nusaniwe. Pihak kelurahan mengemukakan alasan tentang fungsi koordinasi BKM yang tidak berjalan dengan baik; sedangkan di pihak lain, BKM menganggap bahwa pihak kelurahan terlalu jauh mengintervensi kerja BKM, bahkan cenderung menghambat pelaksanaan program BKM.

\section{e. Pendapat BKM Tentang Program P2KP}

Berdasarkan hasil temuan di lapangan, diperoleh data dari $13 \mathrm{BKM}$ bahwa mereka begitu antusias terhadap program dari Pemerintah. Menurut mereka, program yang dilaksanakan oleh pemerintah ini benar-benar memberikan manfaat bagi warga dalam meningkatkan taraf hidup mereka. Program ini lebih menyentuh ke masyarakat jika dibandingkan dengan programprogram desa atau kelurahan yang kerap lambat bahkan jarang terlihat realisasinya.

Adanya peningkatan program-program pemerintah bagi masyrakat miskin dikarenakan masih banyak warga miskin yang tinggal di perkotaan. Dari 13 BKM yang diwawancarai, umumnya mereka sangat mengharapkan agar kegiatan / program ini tetap ada dan berlangsung untuk membantu keluarga yang miskin.

\subsection{KSM (Kelompok Swadaya Masyarakat) a.Proses Seleksi}

Proses seleksi terhadap warga miskin penerima manfaat dilakukan oleh BKM bersamasama pihak desa/kelurahan sesuai dengan data yang diajukan. Penentuan KSM berdasarkan program yang akan dilaksanakan. Umumnya, ketua KSM adalah kepala keluarga ataupun orang yang dipandang dapat bertanggung jawab dalam pelaksanaan tugas.

Berdasarkan temuan di lapangan, diperoleh data bahwa kebanyakan KSM, sebagai penerima manfaat, ditentukan berdasarkan kriteria dan validasi data KK miskin, sehingga memenuhi syarat untuk menerima program bantuan. Dari data tersebut, kemudian ditentukan KK yang akan mendapatkan bantuan, dengan tetap memperhitungkan besaran biaya atau dana yang diperoleh. Sebelum bantuan diberikan, BKM beserta Faskel melakukan validasi lapangan untuk melihat secara dekat kondisi dan situasi KK penerima manfaat. Setelah proses validasi berkas maupun situasi di lapangan telah dilakukan, maka kepala keluarga dipanggil oleh BKM dan Faskel ke kelurahan untuk menerima penjelasan terkait 
program yang akan diberikan atau diterima oleh mereka.

Berdasarkan hasil wawancara dengan beberapa KK di 13 wilayah, ditemukan bahwa pemahaman akan program yang dilakukan/dilaksanakan tidak dipahami secara baik, sehingga memperlihatkan kecenderungan bahwa penerima manfaat hanya mengikuti programnya saja, atas dasar manfaat yang diperolehnya, tanpa memahami dengan baik tujuan dan sasaran dari program itu sendiri. Umumnya warga penerima langsung bantuan menganggap bahwa program bantuan pemerintah ini bermanfaat bagi mereka. Namun secara konseptual, mereka tidak memandang manfaat yang diperoleh itu bagi kepentingan masyarakat secara umum. Mereka hanya memahami bahwa kerap bantuan yang mereka terima mendatangkan sikap sinis dari keluarga lain yang tidak menerima bantuan.

Proses seleksi kerap menimbulkan masalah sehingga untuk mengatasinya, ada BKM yang menggunakan cara mengundi. Dengan cara mengundi, maka diharapkan tidak menimbulkan kecemburuan dari pihak yang belum atau tidak mendapatkan jatah menerima bantuan.

\section{b. Kriteria}

Penentuan kriteria berdasarkan validasi berkas maupun lapangan dengan kriteria sebagai berikut:

1. Terdaftar dalam kartu KK Miskin

2. Kondisi ekonomi keluarga dibawah stándar minimal

3. Usulan dari RT setempat, terkait kondisi keluarga maupun kondisi lingkungan.

Berdasarkan temuan yang ada, penentuan kriteria keluarga miskin disesuaikan dengan prioritas kebutuhan mereka. Hal itu dimaksudkan agar sasaran bagi penerima manfaat dapat tepat pada sasarannya. Beberapa program yang telah dilaksanakan menunjukkan kesesuaian dengan kriteria tersebut. Perbaikan rumah miskin dilakukan berdasarkan kondisi rumah yang ditempati tidak memenuhi stándar kehidupan yang layak, atau tidak layak huni. Pembuatan jamban keluarga didasarkan atas kondisi lingkungan yang tidak ditunjang oleh MCK. Pembuatan jalan setapak disebabkan karena akses jalan bagi warga, sudah tidak layak lagi digunakan.

Situasi dan kondisi ini menunjukan bahwa masyarakat masih membutuhkan bantuan-bantuan untuk peningkatan kualitas hidup mereka.

\section{c. Jenis Program yang Diterima}

KSM penerima manfaat program P2KP pada 13 desa/kelurahan hampir keseluruhan mendapat anggaran untuk program lingkungan, sementara satu desa/kelurahan memperoleh ekonomi bergulir dan desa yang lainnya mendapatkan bantuan sosial berupa pelatihan pembuatan kursi rotan. KSM yang memperoleh bantuan lingkungan terdiri dari $37 \mathrm{KSM}$ dari 13 Desa dan Kelurahan sementara ekonomi bergulir dan bantuan sosial masing-masing $1 \mathrm{KSM}$, yaitu di Kelurahan Kudamati dan Benteng.

Program yang diterima lebih banyak dalam bentuk fisik seperti rehabilitasi rumah miskin, perbaikan dan pembuatan jalan setapak, pembuatan jamban keluarga, pengalian sumur bor/pipanisasi, dan pembuatan bak penampung.

\section{d. Proses Penerimaan Manfaat}

Pentahapan penerima manfaat program biasanya dilakukan di balai desa, disaksikan oleh BKM, Faskel, Kepala Desa/ Lurah, serta masyarakat lainnya. Dana untuk KSM tidak langsung diserahkan kepada KSM tapi melalui rekening BKM. Hal ini dimaksudkan untuk mempermudah pengontrolan terhadap pemakaian dari masing-masing KSM. Setiap KSM dari masing-masing desa/kelurahan menerima anggaran sesuai dengan program yang diberikan. Untuk program lingkungan, jenis program yang dilaksanakan adalah renovasi rumah miskin, pembuatan dan perbaikan jalan, serta perbaikan jamban keluarga. Untuk renovasi rumah miskin, dana yang dibutuhkan bervariasi antara Rp. 15,5 juta-Rp 17,5 juta. Untuk pembuatan jalan anggarannya mencapai Rp 17 juta-Rp 22,5 juta. Setiap desa/kelurahan berbeda dalam penerimaan anggaran program, sedangkan jamban keluarga memperoleh anggaran sebesar Rp 5 jutaan ke atas termasuk swadaya masyararakat. Untuk program di bidang ekonomi, setiap KSM diberikan Rp 750 ribu /orang, sedangkan bidang sosial memperoleh dana Rp 3,75 juta untuk pelatihan dan pembuatan kursi dari bahan baku bambu.

Proses penerimaan bantuan yang seharusnya diterima oleh KSM penerima manfaat di kelurahan Benteng mengalami sedikit keterlambatan dalam proses finishing rumah. Hal ini disebabkan karena adanya tekanan dari RT setempat pada saat KSM tersebut menerima dana untuk pembangunan rumah. Dalam prosesnya, RT yang juga anggota BKM mengambil alih proses pembuatan rumah dengan mempekerjakan keluarganya. Temuan yang diperoleh, rumah 
KSM Canon di Benteng belum selesai, bahkan terlihat belum melakukan penutupan bagian atap dan dinding semen. Dana yang diterima oleh KSM Canon sebesar Rp 15, 25 juta. Menurut keterangan yang disampaikan oleh KSM bahwa uang tersebut dipegang oleh RT tempat tinggal KSM. Hal ini sering dikonfirmasikan namun tidak ada jawaban yanng diberikan oleh RT terhadap KSM. Kondisi seperti telah merugikan penerima manfaat.

Kebutuhan akan air juga menjadi salah satu hal yang sangat urgen dalam kehidupan masyarakat. Salah satu program untuk mengatasi kesulitan air adalah melalui pembuatan sumur bor dan pengadaan mesin Sanyo.

\section{e. Dampak yang Dirasakan}

Program yang baik adalah program yang dapat memberikan manfaat bagi orang yang merasakan manfaat tersebut. Berdasarkan temuan lapangan dan wawancara yang dilakukan terhadap KSM-KSM penerima manfaat program P2KP, diperoleh data bahwa mereka sangat merasakan perubahan yang cukup berarti dalam peningkatan kualitas kesejahteraan mereka terutama bagi KSM yang rumahnya di perbaiki maupun dibuat yang baru. Adanya perubahan dalam kehidupan mereka terkait dengan program yang diterima. Selain penerima manfaat yang rumahnya diperbaiki atau dibuat yang baru. Penerima manfaat yang lain seperti pembuatan jamban keluarga, menunjukkan bahwa mereka sangat bersyukur dan berterima kasih terhadap pemerintah melalui program P2KP. Dengan program pembuatan jamban, mereka tidak lagi membuang hajat ke laut atau ke rumah tetangga.

Manfaat yang dirasakan oleh warga masyarakat terhadap bantuan yang diberikan pemerintah melalui program pengentasan kemiskinan membawa dampak yang positif bagi peningkatan kualitas hidup masyarakat.

\section{f. Harapan Terhadap Program}

Mahluk hidup memerlukan tempat yang layak untuk dihuni, ketika kebutuhan akan perubahan yang layak diterima maka peningkatan akan kualitas hidup yang lebih baik akan terpenuhi. Situasi seperti inilah yang selalu menjadi dambaan setiap orang tanpa terkecuali seperti juga para penerima manfaat, dalam hal ini KSM. 39 KSM penerima manfaat mengharapkan agar program-program pemerintah tetap dipertahankan untuk membantu warga masyarakat yang masih banyak membutuhkan uluran tangan dari semua pihak, terutama pemerintah melalaui Program P2KP.

KSM begitu terharu terutama mereka yang menerima bantuan seperti perbaikan rumah dan pembuatan rumah baru dan juga jamban keluarga. Mereka sangat merasakan perbedaan yang cukup signifikan dalam kehidupan mereka setelah menerima bantuan.

\subsection{Proses Seleksi BKM dan KSM}

Seleksi merupakan tahap awal dan sangat menentukan proses program selanjutnya. Proses seleksi dalam program ini terdiri dari seleksi terhadap BKM dan KSM. Hasil temuan lapangan menunjukkan bahwa penyeleksian terhadap anggota BKM melalui sebuah mekanisme pemillihan yang telah disepakati. Proses penyeleksian ini merupakan titik krusial dalam proses awal program adalah kesepakatan yang dilakukan oleh pihak P2KP dengan BKM dimasing-masing wilayah melalui program $\mathrm{P} 2 \mathrm{KP}$

Data lapangan menunjukkan, bahwa seleksi terhadap BKM dalam menjalankan program dibutuhkan tanggungjawab dan loyalitas yang tinggi mengingat anggota $\mathrm{BKM}$ tidak digaji seperti pengawai di instansi lain sehingga memudahkan siapapun untuk keluar dan masuk dalam program jika ada kejenuhan dalam melaksanakan tugas yang diembannya.

Untuk KSM sebagai penerima manfaat, lebih banyak berperan sebagai eksekutor terhadap program yang dilaksanakan. Hal itu terjadi karena manfaatnya dirasakan secara langsung oleh mereka. Itu menyebabkan orientasi mereka lebih terfokus pada bagaimana menyelesaikan pekerjaan dengan dana yang ada, daripada memperhatikan fungsi program bagi kepentingan masyarakat. Dengan kata lain, manfaat yang dirasakan lebih bersifat parsial dan tidak holistik. Kenyataan itu memberi indikasi adanya proses seleksi yang menuai kecemburuan. Di samping itu, pemahaman tentang program bantuan pemerintah, dengan dana yang ada batasannya namun terarah pada kepentingan masyarakat, ternyata tidak dimengerti oleh masyarakat maupun KSM sendiri. Indikator yang dapat disebutkan di sini, misalnya pada renovasi rumah miskin, kadang harus dikerjakan sendiri tanpa bantuan dari masyarakat lain. Itu berarti pada proses seleksi, masih ada yang tidak berjalan sesuai prosedur yang ditetapkan. 


\subsection{Proses Penentuan Kriteria BKM dan KSM}

Dari temuan di lapangan dapat dikatakan bahwa proses penentuan BKM dan KSM tidak seluruhnya berjalan sesuai dengan prosedur atau mekanisme pembentukannya. Meskipun ada upaya untuk dapat mengatasi persoalan penentuan kriteria melalui prosedur dan mekanisme yang telah ditetapkan, namun tidak semudah itu dilaksanakan. Temuan di lapangan yang menunjukkan adanya prosedur "lain" disebabkan karena konteks masyarakat sendiri. Sistem kekerabatan menjadi penyebab utama sehingga proses penentuan kriteria kerap tidak berjalan dengan semestinya.

Umumnya ditemukan bahwa koordinator BKM dapat menjalankan tugasnya selama beberapa tahun, oleh karena sulit ditemukan penggantinya. Sebaliknya, anggota BKM kadang berganti oleh karena alasan tidak memberi manfaat secara finansial. Akibatnya, hal ini juga turut berdampak pada penentuan KSM. Posisi BKM memberi cukup ruang untuk menetapkan kebijakan sendiri di luar prosedur seharusnya.

Di beberapa tempat yang sebagian besar warga masyarakatnya terikat hubungan kekeluargaan, prioritas penentuan KSM kerap "terpaksa" memperhitungkan sisi hubungan kekelurgaan itu. Konsekwensi yang diterima bisa saja kecaman, jika penentuan KSM dianggap memihak keluarga; atau bisa juga keraguan dalam menentukan metode penentuan oleh karena pertimbangan rasa. Dengan demikian, dapat dikatakan bahwa penilaian yang muncul sebagian besar dapat cenderung negatif dari masyarakat. Namun di sisi lain, BKM dapat melakukan pembelaan atas dasar posisi mereka yang tidak diisi atau digantikan oleh orang lain, ditambah dengan atensi dari pihak-pihak tertentu yang mengharapkan manfaat finansial namun tidak mau terlibat, mengakibatkan setiap kebijakan yang ditempuh dianggap legal.

\subsection{Proses Pelaksanaan Program}

Pelaksanaan program yang dilakukan adalah ketika KSM mendapatkan anggaran melalui rekening BKM, untuk membelikan kebutuhan terkait dengan jenis program yang diberikan. Jika melihat dari hasil temuan lapangan, bahwa program diberikan bagi KSM di satu sisi sangat membantu kehidupan mereka. Namun di lain sisi, KSM sesungguhnya tidak memperoleh kesempatan untuk mengelola keuangan mereka sendiri. Menurut Muhamad Yunus dalam bukunya, Menciptakan Dunia Tanpa Kemiskinan,
"Sesungguhnya orang miskin dapat melakukan apapun juga, yang terpenting adalah bagaimana kita menanamkan rasa kepercayaan untuk merubah pola pikir mereka terhadap sesuatu."

Jika proses pelaksanaan program itu dilaksanakan dengan tidak semestinya, maka tentunya penilaian yang cenderung negatif dapat mengakibatkan manfaat dari program tersebut tidak dapat dirasakan secara menyeluruh oleh masyarakat. Fakta yang ditemui di lapangan memberi isyarat bahwa prosedur pelaksanaan program harus memperhitungkan konteks sosial budaya setempat. Meskipun kebijakan yang diambil tidak merugikan program, namun dari segi manfaatnya bagi kepentingan umum, dirasa belum tercapai secara maksimal, mengingat masih ada warga yang menilai secara negatif. Manfaat yang seharusnya dirasakan secara holistik justru lebih dirasakan hanya secara parsial atau hanya bagi sebagian masyarakat yang merasakan langsung dampaknya.

\subsection{Dampak}

Program ini menimbulkan dampak secara langsung maupun tidak langsung bagi masyarakat terutama penerima manfaat. Dampak secara langsung bagi KSM dan dampak yang tidak langsung yaitu bagi BKM.

Dampak adalah suatu reaksi yang ditunjukan oleh seseorang terhadap sesuatu, dalam hal ini kelompok swadaya masyarakat yang memiliki ekonomi menengah ke bawah, kebijakan yang diambil oleh pemerintah melalui program P2KP memberikan suatu stimulus yang mampu merubah suatu kondisi masyarakat yang berada dibawah garis kemiskinan. Kondisi sosial masyarakat yang memiliki tempat tinggal tidak layak huni mengalami perubahan yang cukup signifikan dalam meningkatkan kualitas hidup mereka. Dari 39 KSM yang mendapatkan program P2KP, mereka merasakan secara langsung dampak yang ditimbulkan oleh kebijakan pemerintah melalui program pengentasan kemiskinan.

\section{Kesimpulan dan Saran}

\subsection{Kesimpulan}

1. Pemberdayaan terhadap masyarakat miskin melalui program P2KP merupakan suatu bentuk intervensi pemerintah dalam rangka mengurangi kemiskinan di perkotaan.

2. Upaya-upaya yang telah dilakukan bukan hanya dititikberatkan kepada pembangunan fisik semata, tapi turut pula berimplikasi pada pemberdayaan sumber daya manusia. 
3. Koordinasi antara elemen yang terkait dalam program sering menjadi masalah, oleh karena masing-masing merasa memiliki kepentingan dengan pelaksanaan program tersebut.

4. Pengentasan kemiskinan bagi masyarakat, walaupun memberikan dampak yang positif, namun tidak jarang menuai penilaian yang cenderung negatif di kalangan masyarakat, khususnya pada praktik pelaksanaan oleh para pemangku kepentingan (stakeholder).

\section{2. $\underline{\text { Saran }}$}

1. Perlu adanya pelatihan Capacity Building bagi BKM untuk meningkatkan pengetahuan tentang pendokumentasian yang baik sehingga mereka tidak hanya memahami program tapi juga bagaimana melakukan dokumentasi yang baik terhadap program yang dilaksanakan.

2. Perlu memberikan penjelasan dan pemahaman yang baik kepada penerima manfaat tentang program-program yang diperuntukan bagi mereka, sehingga manfaatnya tidak hanya dirasakan bagi kepentingan mereka, tetapi juga dipahami sebagai kepentingan bersama dalam konteks bermasyarakat.

3. Perlu disediakan tempat yang sesuai (sekretariat) untuk membantu kinerja BKM dalam pelaksanaan program yang dilakukan.

4. Perlu adanya mekanisme pembagian anggaran bagi setiap wilayah yang sesuai dengan jumlah penduduk miskin di wilayah tersebut.

5. Perlu memperhatikan konteks sosial budaya setempat sehingga prosedur dan mekanisme pelaksanaan program tidak menimbulkan kecemburuan atau bias.

\section{REFERENSI}

Adi, Isbandi Rukminto. 2008. Intervensi Komunitas: Pengembangan Masyarakat Sebagai Upaya Pemberdayaan Masyarakat. Jakarta: PT Grafindo Persada.

Creswell, Jhon W. 2010. Research Design: Pendekatan Kualitatif, Kuantitatif, dan Mixed. Yogyakarta: Pustaka Pelajar

Huraerah, Abu. 2008. Pengorganisasian dan Pengembangan Masyarakat: Model dan
Strategi Pembangunan Berbasis Kerakyatan. Bandung: Humaniora

Sherraden, Michael. 2006. Aset Untuk Orang Miskin: Perspektif Baru Usaha Pengentasan Kemiskinan. Jakarta: Grasindo Perkasa

Soetomo. 2008. Masalah Sosial dan Upaya Pemecahannya. Yogyakarta: Pustaka Pelajar

Sudrajat dan Subana. 2009. Dasar-Dasar Penelitian Ilmiah. Bandung: CV Pustaka Setia

Suharto, Edy.2009. Kemiskinan dan Perlindungan Sosial di Indonesia: Menggagas Model Jaminan Sosial Universal Bidang Kesehatan. Bandung: Refika Aditama

Usman, Sunyoto. 2010. Pembangunan dan Pemberdayaan Masyarakat. Yogyakarta, Pustaka Pelajar

* Nancy Rahakbauw. S.Sos., M.Si, Dosen Universitas Kristen Indonesia Maluku (UKIM) Ambon 